\title{
Hepatitis Associated Antigen (HAA) in Leprosy*
}

\author{
G. J. PAPAEVANGELOU, J. PAPASTAVROPOULOS and T. KOUREA \\ Department of Hygiene and Epidemiology, \\ University of Athens, Greece
}

\begin{abstract}
This report confirms earlier findings of the increased frequency of HAA in leprosy patients. This association is investigated in relation to various characteristics of the sample studied. It is concluded that the impaired immune mechanism in lepromatous leprosy is mainly responsible for the observed association, rather than other factors such as treatment or confinement of the patient
\end{abstract}

\section{Introduction}

The close association of the hepatitis-associated antigen (HAA) with viral hepatitis has been well established (Blumberg et al., 1967a; Memorandum, 1970; Papaevangelou et al., 1971). Its increased frequency in lepromatous leprosy and in other chronic diseases characterized by impairment of the immune mechanism, has been reported (Blumberg et al., 1967b; London et al., 1969; Salazar Mállen et al., 1970). However, Salzano and Blumberg (1970) suggested that this is true only for areas where HAA is common in the general population. We have therefore studied the distribution of HAA in 427 leprosy patients in order to investigate its possible relation to the various characteristics of these patients. The findings of this study are here reported.

\section{Materials and Methods}

We examined 427 leprosy patients born and living in various regions of Greece. They comprise one-third of all the leprosy patients in Greece under close observation; 363 of them were in-patients at the only residential institution for leprosy in Greece, the Infectious Diseases Hospital, Athens. The remaining 64 patients were under treatment at the out-patient clinic of the same institution.

Patients were carefully examined and a complete questionnaire about their past history and present condition was completed. Thus, we were able to classify them by leprosy type, viz: lepromatous 187 , tuberculoid 153 , and indeterminate 87 and to cross-classify them by age, sex, duration of the disease, bacteriological status, and type of treatment received. The differences in the incidence of HAA among the various subgroups of each characteristic studied were compared after standardization for the type of disease (Armitage, 1971). The presence of Myco. leprae was determined by special examination of the leprosy lesions as well as from the naso-pharyngeal mucosa and the blood.

* Received for publication 27 November, 1971. 
The double immunodiffusion technique in $0.9 \%$ agarose, as described by Prince (1968), was used for the detection of HAA. Blood samples were collected under aseptic conditions and sera were separated immediately and kept at $-20^{\circ} \mathrm{C}$ till tested. The serum of a patient with polytransfused thalassaemia served as the source of antibody; its titre varied between $1 / 16$ and $1 / 64$. Reactions of immunological identity were obtained with reference antisera kindly provided by Dr Blumberg and Prince.

\section{Results}

HAA was detected in $17(4.0 \%)$ out of the 427 patients examined. Its frequency was equally high in the lepromatous $(5.9 \%)$ and indeterminate $(5.7 \%)$ type of leprosy, but significantly $(P<0.05)$ lower $(0.7 \%)$ in the tuberculoid type of the disease. Table 1 shows the incidence of HAA by the characteristics studied

TABLE 1

Comparison of the frequency of $H A A$ by various epidemiological characteristics before and after standardization for the type of leprosy

\begin{tabular}{|c|c|c|c|c|c|}
\hline \multicolumn{2}{|c|}{ Comparison } & \multirow{2}{*}{$\begin{array}{c}\text { No. } \\
\text { Patients } \\
241 \\
186\end{array}$} & \multirow{2}{*}{$\begin{array}{c}\text { HAA } \\
\text { positive } \\
11 \\
6\end{array}$} & \multirow{2}{*}{$\begin{array}{c}\begin{array}{c}\text { Crude } \\
\text { frequency } \\
(\%)\end{array} \\
4.6 \\
3.2\end{array}$} & \multirow{2}{*}{$\begin{array}{c}\text { Frequency (\%) } \\
\text { after standard. } \\
\begin{array}{c}\text { For type of } \\
\text { disease }\end{array} \\
4.1 \\
3.8\end{array}$} \\
\hline Sex & $\left\{\begin{array}{l}\text { Males } \\
\text { Females }\end{array}\right.$ & & & & \\
\hline Age (years) & $\left\{\begin{array}{l}<30 \\
30-49 \\
>50\end{array}\right.$ & $\begin{array}{r}24 \\
167 \\
236\end{array}$ & $\begin{array}{l}1 \\
7 \\
9\end{array}$ & $\begin{array}{l}4.2 \\
4.2 \\
3.8\end{array}$ & $\begin{array}{l}3.7 \\
3.6 \\
4.1\end{array}$ \\
\hline $\begin{array}{l}\text { Duration of } \\
\text { disease (years) }\end{array}$ & $\left\{\begin{array}{l}<5 \\
5-14 \\
>15\end{array}\right.$ & $\begin{array}{r}89 \\
158 \\
180\end{array}$ & $\begin{array}{l}1 \\
7 \\
9\end{array}$ & $\begin{array}{l}1.1 \\
4.4 \\
5.5\end{array}$ & $\begin{array}{l}1.0 \\
5.2 \\
4.5\end{array}$ \\
\hline $\begin{array}{l}\text { Confinement to } \\
\text { Institution }\end{array}$ & $\left\{\begin{array}{l}\text { In-patients } \\
\text { Out-patients }\end{array}\right.$ & $\begin{array}{r}363 \\
64\end{array}$ & $\begin{array}{r}15 \\
2\end{array}$ & $\begin{array}{l}4.1 \\
3.1\end{array}$ & $\begin{array}{l}4.2 \\
3.0\end{array}$ \\
\hline $\begin{array}{l}\text { Bacteriological } \\
\text { status }\end{array}$ & $\left\{\begin{array}{l}\text { Positive } \\
\text { Negative }\end{array}\right.$ & $\begin{array}{l}112 \\
315\end{array}$ & $\begin{array}{r}1 \\
16\end{array}$ & $\begin{array}{l}0.9 \\
5.1\end{array}$ & $\begin{array}{l}0.7 \\
5.8\end{array}$ \\
\hline Treatment & $\left\{\begin{array}{l}\text { Parenteral } \\
\text { Oral }\end{array}\right.$ & $\begin{array}{r}70 \\
357\end{array}$ & $\begin{array}{r}4 \\
13\end{array}$ & $\begin{array}{l}5.7 \\
3.6\end{array}$ & $\begin{array}{l}5.4 \\
3.7\end{array}$ \\
\hline
\end{tabular}

before and after adjustment for the type of leprosy. hAA is more common in males $(4.1 \%)$ than in females $(3.8 \%)$, but the difference does not reach the $5 \%$ level of significance. HAA frequency does not vary significantly $(P>0.1)$ with the age of the leprosy patients. The frequency is slightly higher in the in-patients $(4.2 \%)$ than in the out-patients $(3.0 \%)$ and also in patients treated parenterally $(5.4 \%)$ than in those under oral treatment $(3.7 \%)$, but in both comparisons that difference is not statistically significant $(P<0.05)$. The frequency of HAA increases with increasing duration of the disease, being lowest in those with disease of less than 5 years' duration (1.0\%). HAA is not associated with the detection of Myco. leprae. Its frequency is significantly $(P<0.05)$ higher in the absence $(5.1 \%)$ than in the presence $(0.9 \%)$ of Myco. leprae. 


\section{Discussion}

HAA is common in the general population of Greece; its frequency in a representative sample of healthy persons was found to be $1.9 \%$ (Papaevangelou $\&$ Kourea, 1972). In the present study we were able to confirm the increased frequency of HAA in leprosy patients previously reported (Blumberg et al., 1967b; Salazar Mállen et al., 1970). Thus HAA was more common in the leprosy patients studied $(4.0 \%)$ than in the general population. Comparisons among the patients showed that this association was apparent for those with the lepromatous and indeterminate types of the disease. However, HAA was less common in patients with tuberculoid leprosy than in the general population.

Alterations in some aspects of immunological reactivity, including decreased reactivity to lepromin, generalized impairment of delayed hypersensitivity (Wld Hlth Org., 1970), and impaired lymphocyte transformation have been reported (Sheagren et al., 1969). Salzano and Blumberg (1970) suggested that the increased frequency of HAA in lepromatous leprosy, as well as in other chronic diseases (such as Down's syndrome, etc.), is due to an inadequate immune mechanism, which renders such patients more susceptible to chronic infection with hepatitis.

We studied the effects of the other factors after correcting for the observed different frequency of HAA in relation to type of leprosy. Our results are not much at variance with the findings of Blumberg et al. (1967b) as far as the sex distribution of HAA in leprosy patients is concerned, although the observed increased frequency in males did not reach the $5 \%$ level of significance in our sample. However, we were not able to confirm the reported decrease in the frequency of HAA with increased age of leprosy patients (Blumberg et al., $1967 b)$.

The majority of the patients were confined in a residential institution, but some patients with lepratomous, indeterminate or tuberculoid disease were treated as out-patients. After correction for the type of leprosy, the frequency of HAA was not significantly higher in in-patients than in out-patients $(P>0.1)$.

HAA is associated with the serum hepatitis (B) type of virus (Krugman \& Giles, 1970). In the sample studied HAA was more common in patients under parenteral treatment than in those treated orally, but the difference was not significant $(P>0.1)$. It is believed therefore that neither admission to hospital, which helps the spread of infectious diseases transmitted through the oral-faecal route, nor iatrogenic transmission is mainly responsible for the increased frequency of HAA observed in leprosy patients.

HAA does not seem to be related to the presence of Myco. leprae or to products of the host's reaction to it. The presence of this organism was not associated with the detection of HAA; on the contrary, in the patients negative for Myco. leprae, HAA was more common. This is in agreement with the increased frequency of HAA observed in patients who had had the disease for more than 5 years.

The observed increased frequency of HAA in lepromatous leprosy patients is thus mainly due to impairment of the immune mechanism, which renders them more susceptible to infection with the hepatitis virus and also interferes with its elimination. Iatrogenic transmission, lower health standards associated with confinement, or other factors seem to be of less importance. 


\section{References}

Armitage, P. (1971). In Statistical Methods in Medical Research. p. 388. Oxford: Blackwell Scientific Publications.

Blumberg, B. S., Gerstley, B. J. S., Hungerford, D. A., London, W. T. and Sutnick, A. I. (1967a). A serum antigen (Australian antigen) in Down's syndrome, leukemia and hepatitis. Ann. intern. Med. 66, 924.

Blumberg, B. S., Melartin, L., Lechat, M. and Guinto, R. (1967b). Association between lepromatous leprosy and Australian antigen. Lancet ii, 173.

Krugman, S. and Giles, J. P. (1970). Viral hepatitis. New light on an old disease. J. Amer. med. Ass. $212,1019$.

London, W. T., Sutnick, A. I. and Blumberg, B. S. (1969). Australian antigen and acute hepatitis. Ann. intern. Med. 70, 55.

Memorandum. (1970). Viral hepatitis and tests for the Australia (hepatitis-associated) antigen and antibody. Bull. Wld Hlth Org. 42, 957.

Papaevangelou, G. J., Kourea, T. and Tsoukas, S. (1971). Hepatitis-associated antigen in acute viral hepatitis in Greece. Path. Microbiol. 37, 361.

Papaevangelou, G. J. and Kourea, T. (1972) Frequency of HAA in a representative sample of healthy Greek persons. Acta Microb. Hell. 17, 99.

Prince, A. M. (1968). An antigen detected in the blood during the incubation period of serum hepatitis. Proc. nat. Acad. Sci., Wash. 60, 814.

Salzano, F. M. and Blumberg, B. S. (1970). The Australia antigen in Brazilian healthy persons and in leprosy and leukemia patients. J. clin. Path. 23, 39.

Sheagren, J. N., Block, J. B., Trautman, J. R. and Wolfe, S. M. (1969). Immunologic reactivity in patients with leprosy. Ann. intern. Med. 70, 295.

World Health Organization (1970). WHO expert committee on leprosy: Fourth report. Wld Hlth Org. Techn. Rep. Ser. No. 459, Geneva. 